\title{
PERANAN PENGENDALIAN INTERNAL PERSEDIAAN BARANG DAGANG DALAM MENUNJANG EFEKTIVITAS PENGELOLAAN PADA STUDI KASUS: PT. SAMSUNG ELECTRONICS INDONESIA CABANG MANADO
}

\author{
Oleh \\ Prilly Lakoy \\ Agus Toni Poputra \\ Program Pendidikan Profesi Akuntansi \\ Fakultas Ekonomi dan Bisnis \\ Universitas Sam Ratulangi Manado \\ Email: prillysyeren@gmail.com
}

\begin{abstract}
This study aimed to analyze the role of internal control in supporting goods inventory for effectiveness of goods inventory at PT. Samsung Electronics Indonesia Manado branch located at Jl. Toar No. 1, Manado North Sulawesi in the electronics division. This type of research used descriptive analysis by observing the understanding of internal control procedures through tests of controls, then documenting the company's internal control information using a process flow chart, goods reception and delivery of goods as well as elements of internal control are applied. The data used in this study are primary data and secondary data. primary data obtained from interviews and direct observation and secondary data obtained through the literature related to control testing, company documentation, the data types available in warehouse stock inventory, shipping and receiving process flow of goods and other data related to this study. The results showed PT. Samsung Electronics Indonesia in Manado branch has been quite effective in performing internal control both in its application through the five elements, namely elements of the control environment, risk assessment, control activities, information and communication and monitoring.
\end{abstract}

Keyword: Internal Control, Goods Inventory

\section{PENDAHULUAN}

\section{Latar Belakang}

Pada saat ini banyak masyarakat yang berlomba-lomba untuk menjalankan usaha baik itu di bidang perdagangan, transportasi, teknologi, pertanian, peternakan dan berbagai jenis usaha lainnya. Dalam menjalankan usaha tersebut banyak hal yang harus diperhatikan salah satunya adalah pengendalian. Pengendalian dilakukan dengan tujuan agar apa yang telah direncanakan dapat dilaksanakan dengan baik sehingga dapat mencapai target maupun tujuan yang ingin dicapai (Fariyanti, 2013).

Salah satu jenis pengendalian yang penting untuk dilakukan yaitu pengendalian internal. Pengendalian internal adalah seperangkat kebijakan yang meliputi struktur organisasi, metode, ukuran-ukuran untuk melindungi aset atau kekayaan perusahaan, mengecek ketelitian dan keandalan data akuntansi, mendorong efisiensi dan dipatuhinya kebijakan manajemen (Seredei dan Runtu, 2015). Pengendalian internal juga merupakan aktivitas memonitor secara terus menerus untuk memastikan bahwa hasilnya akan berada dalam batasan yang diinginkan dan dari setiap aktivitas perusahaan yang 
dilakukan harus dibandingkan dengan rencana apabila terdapat perbedaan yang signifikan maka perlu diadakan tindakan perbaikan (Fariyanti, 2013)

Pada dasarnya dalam mengelola aktivitas perusahaan dagang dan manufaktur sangat perlu diperhatikan adalah aktivitas pengendalian persediaan barang dagang. Persediaan barang dagang merupakan kunci utama dalam jenis usaha dagang. Hal ini bisa dilihat ketika terjadi masalah dalam persediaan maka akan terganggu pula semua kegiatan operasional perusahaan. Contohnya, keterlambatan pengiriman persediaan. Ketika persediaan kosong karena terlambat, maka kegiatan operasional perusahaan juga terhenti (Syailendra, 2013). Persediaan berlebihan juga tidak baik bagi perusahaan. Persediaan berlebihan bisa menyebabkan besarnya nilai investasi dalam persediaan sehingga berpengaruh terhadap keuntungan perusahaan. Oleh karena itu, perusahaan perlu mengendalikan persediaan agar bisa tetap eksis dan terus memenuhi kegiatan operasional untuk mencapai target serta keuntungan yang ingin dicapai.

Selain itu, pengendalian internal atas persediaan barang dagang dimulai pada saat barang diterima, penyimpanan, sampai saat barang-barang yang siap untuk dijual (Makisurat, Morasa, dan Elim, 2014). Dengan adanya pengendalian internal dapat mencegah timbulya bentuk kecurangan, penyelewangan, dan praktik-praktik yang tidak sehat yang terjadi di dalam perusahaan (Rahmawati, 2010).

Berdasarkan beberapa penelitan yang telah dilakukan sebelumnya terdapat beberapa hasil penelitan mengenai peranan pengendalian internal persediaan barang dagangan dalam menunjang efektivitas pengelolahan persediaan barang dagang. Penelitian oleh Rahmawati (2010) menunjukkan dari kertas kerja penilaian pengendalian internal atas persediaan barang farmasi dapat disimpulkan sistem pengendalian internal yang diterapkan pada PT. Kimia Farma Trading dan Distribution Surakarta dinilai kuat.

Hal ini dapat diketahui dengan adanya sistem pengendalian internal yang diterapkan oleh perusahaan pada sistem pengadaan barang farmasi yaitu setiap penerimaan barang harus terdapat surat pesanan yang telah diotorisasi, barang yang dikeluarkan dari gudang hanya atas dasar surat pemesanan pengiriman yang telah diotorisasi, pemisahan fungsi ekspedisi dari fungsi faktur, dan pembuatan dokumen pengiriman barang. Selanjutnya, penelitian oleh Mulyani (2013) hasil penelitian menunjukkan pengendalian internal atas persediaan pada PT. Grokindo sudah cukup efektif, dimana adanya pemisahaan diantara fungsi-fungsi terkait dengan penerimaan dan pengeluaran barang, pemantauan terhadap persediaan barang dagangan juga dilakukan secara periodik oleh bagian logistik melalui kegiatan stock opname.

Selain itu penelitian oleh Makisurat, Morasa, dan Elim (2014) hasil penelitian menunjukkan penerapan pengendalian internal atas barang dagangan pada CV. Multi Media Persada Manado sudah baik karena telah menerapkan unsur-unsur pengendalian internal serta disarankan untuk menyediakan staf ahli dalam menilai kualitas barang dagangan. Dari beberapa hasil penelitian sebelumnya menunjukkan pengendalian internal atas persediaan barang dagang sangatlah penting bagi perusahaan dagang. Peninjauan kembali sistem pengendalian internal di perusahaan sangat diperlukan untuk mengurangi resiko-resiko yang terjadi dan bisa mengganggu kegiatan operasional perusahaan.

Salah satu perusahaan dagang yang sudah banyak dikenal oleh masyarakat di Indonesia yaitu PT. Samsung Electronics Indonesia. Perusahaan ini merupakan perusahaan dagang yang bergerak dalam bidang elektronik seperti handphone, TV, kulkas, mesin cuci, AC dan peralatan elektronik lainnya. Di Indonesia, nama perusahaan 
ini sudah sangat populer oleh banyak orang dan merupakan salah satu barang elektronik yang berkualitas baik. Perusahaan Samsung ini pun sudah membuka beberapa cabang di seluruh kota-kota di Indonesia salah satunya Kota Manado.

PT. Samsung Electronics Indonesia memutuskan untuk membuka kantor cabang dan pusat Service Center di Kota Manado dikarenakan masyarakat Kota Manado memiliki sifat konsumtif terhadap tren teknologi, sehingga menjadikan Kota Manado sebagai Kota yang memiliki potensi besar untuk penjualan elektronik dari Samsung. Untuk menjaga stabilitas penjualan Samsung sebagai kantor cabang Samsung Manado tentunya harus mempertahankan sistem pengendalian internal terlebih kepada persediaan barang dagangannya sebagai perusahaan dagang untuk dapat memenuhi kebutuhan konsumen dalam operasional perusahaannya.

Pengendalian internal terhadap persediaan barang dagang di Samsung Manado sudah menggunakan System Application Product (SAP), hal ini membuat hubungan antara sistem informasi pengendalian internal dengan persediaan barang dagang merupakan suatu kesatuan yang saling menunjang sehingga persediaan barang dagang di Samsung Manado terpantau secara rutin dan mendapatkan informasi yang up to date. Namun pada pelaksanaannya seringkali terjadi kendala yang membuat pengendalian internal terhadap pengelolahan persediaan barang dagang terhambat dan tidak sesuai dengan yang ditetapkan. Dari uraian di atas, penulis tertarik untuk melakukan suatu kajian tentang "Peranan Pengendalian Internal Persediaan Barang Dagang Dalam Menunjang Efektivitas Pengelolahan Persediaan Barang Dagangan Pada Studi Kasus : PT. Samsung Electronics Indonesia Cabang Manado"

\section{TINJAUAN PUSTAKA Pengendalian Internal}

Srijantri dan Treesje (2015) menyatakan bahwa pengendalian internal adalah seperangkat kebijakan yang meliputi struktur organisasi, metode, ukuran-ukuran untuk melindungi aktiva atau kekayaan organisasi, mengecek ketelitian dan keandalan data akuntansi, mendorong dipatuhinya kebijakan manajemen.

\section{Tujuan Pengendalian Internal}

Menurut Tunggal (2013), sesuai dengan Standards for The Professional Practice of Internal Auditing, Scope of Work, 5 tujuan utama pengendalian intern adalah sebagai berikut.

1. Keandalan dan integritas informasi.

2. Ketaatan dengan kebijakan, rencana, prosedur, hukum dan peraturan.

3. Mengamankan aktiva.

4. Pemakaian sumber daya yang ekonomis.

5. Pencapaian tujuan dan sasaran operasi atau program yang ditetapkan

Komponen Pengendalian Internal Committee of Supporting Organization of the Tredway Commission (COSO)

Menurut Arens (2008) Internal Control - Integraterd Framework yang dikeluarkan oleh Committee of Supporting Organization of the Treadway Commission (COSO), yaitu kerangka kerja pengendalian yang paling luas diterima di Amerika Serikat, menguraikan lima komponen pengendalian internal yang dirancang untuk diimplementasikan oleh manajemen untuk memberikan kepastian yang layak bahwa tujuan pengendaliannya akan tercapai. Setiap komponen mengandung banyak pengendalian, tetapi auditor hanya berfokus pada pengendalian yang dirancang untuk 
mencegah atau mendeteksi kesalahan dan kecurangan. Komponen pengendalian internal COSO meliputi hal-hal berikut ini.

1. Lingkungan Pengendalian (Control Environment), lingkungan pengendalian terdiri atas tindakan, kebijakan, dan prosedur yang mencerminkan sikap manajemen puncak, para direktur, dan pemilik entitas secara keseluruhan mengenai pengendalian internal serta arti pentingnya bagi entitas itu. Untuk memahami dan menilai lingkungan pengendalian, auditor harus mempertimbangkan sub komponen yang penting.

2. Penilaian Resiko (Risk Assessment), penilaian resiko merupakan tindakan yang dilakukan manajemen untuk mengidentifikasi dan menganalisis risiko-risiko yang relevan dalam penyusunan laporan keuangan yang sesuai dengan Generally Accepted Accounting Principles (GAAP). Sebagai contoh, jika perusahaan sering menjual produk dengan harga di bawah harga pokok persediaan karena pesatnya perubahan teknologi dan

daya saing dengan pesaing lainnya, perusahaan itu harus menyelenggarakan pengendalian yang memadai untuk mengatasi risiko melebihkan persediaan. Demikian pula kegagalan untuk memenuhi tujuan sebelumnya, mutu personil, penyebaran geografis operasi perusahaan, signifikansi dan kompleksitas proses bisnis inti, pengenalan teknologi informulirasi yang baru, dan munculnya pesaing baru, semuanya merupakan contoh faktor-faktor yang dapat meningkatkan risiko.

3. Aktivitas Pengendalian (Control Activities), aktivitas pengendalian merupakan kebijakan dan prosedur, selain yang sudah termasuk dalam komponen lainnya, yang membantu memastikan bahwa tindakan yang diperlukan telah diambil untuk menangani risiko guna mencapai tujuan entitas. Sebenarnya ada banyak aktivitas pengendalian semacam ini dalam entitas mana pun, termasuk pengendalian manual dan terotomatisasi. Aktivitas pengendalian umumnya dibagi menjadi lima jenis yaitu sebagai berikut.

a. Pemisahan tugas yang memadai.

b. Otorisasi yang sesuai atas transaksi dan aktivitas.

c. Dokumen dan catatan yang memadai.

d. Pengendalian fisik atas aktiva dan catatan.

e. Pemeriksaan kinerja secara independen.

4. Informasi dan Komunikasi (Information and Communication), tujuan sistem informasi dan komunikasi akuntansi dari entitas adalah untuk memulai, mencatat, memproses, dan melaporkan transaksi yang dilakukan entitas itu serta mempertahankan akuntabilitas aktiva terkait. Untuk memahami perancangan sistem informulirasi akuntansi, auditor menentukan:

a. Kelas transaksi utama entitas.

b. Bagaimana transaksi dimulai dan dicatat.

c. Catatan akuntansi apa saja yang ada serta sifatnya.

d. Bagaimana sistem itu menangkap peristiwa-peristiwa lain yang penting bagi laporan keuangan.

e. Sifat serta rincian proses pelaporan keuangan yang diikuti, serta termasuk prosedur pencatatan transaksi dan penyesuaian dalam buku besar umum.

5. Pemantauan (Monitoring), aktivitas pemantauan berhubungan dengan penilaian mutu pengendalian internal secara berkelanjutan atau periodik oleh manajemen untuk menentukan bahwa pengendalian itu telah beroperasi seperti yang 
diharapkan, dan telah dimodifikasi sesuai dengan perubahan kondisi. Informasi yang dinilai ini berasal dari berbagai sumber, termasuk studi atas pengendalian internal yang ada, laporan auditor internal, pelaporan pengecualian tentang aktivitas pengendalian, dan umpan balik dari personel operasional.

\section{Persediaan}

Menurut Nurmailiza (2009), persediaan adalah suatu aktiva yang meliputi barangbarang milik perusahaan dengan maksud untuk dijual dalam satu periode usaha yang normal, termasuk barang yang dalam pengerjaan/proses produksi menunggu masa penggunaannya pada proses produksi.

\section{Jenis - Jenis Persediaan}

Jenis - jenis persediaan akan berbeda sesuai dengan bidang atau kegiatan normal usaha perusahaan tersebut. Berdasarkan bidang usaha perusahaan dapat terbentuk perusahaan industri (manufacture), perusahaan dagang, dan ataupun perusahaan jasa. Adapaun untuk perusahaan industri jenis persediaan yang dimiliki adalah persediaan bahan baku (raw material), barang dalam proses (work in process), persediaan barang jadi (finished goods), serta bahan pembantu yang akan digunakan dalam proses produksi, sedangkan perusahaan dagang persediaannya hanya satu yaitu barang dagang. Dari penjelasan di atas, dapat disimpulkan bahwa persediaan barang dagang dapat berupa bahan baku, barang setengah jadi, ataupun barang jadi (Nurmailiza, 2009).

\section{Fungsi Persediaan}

Persediaan memiliki beberapa fungsi penting bagi perusahaan, yaitu sebagai berikut (Aini, 2011).

1. Agar dapat memenuhi permintaan yang diantisipasi akan terjadi.

2. Untuk menyeimbangkan produksi dengan distribusi.

3. Untuk memperoleh keuntungan dari kuantitas, karena membeli dalam jumlah yang banyak ada diskon

4. Untuk hedging dari inflasi dan perubahan harga.

5. Untuk menghindari kekurangan persediaan yang dapat terjadi karena cuaca, kekurangan pasokan, mutu, dan ketidaktepatan pengiriman.

6. Untuk menjaga kelangsungan operasi dengan cara persediaan dalam proses

\section{Pengendalian Internal Atas Persediaan}

Menurut Hery (2009), pengendalian intern atas persediaan seharusnya dimulai pada saat barang diterima. Secara luas komponen pengendalian intern pada persediaan meliputi pengarahan arus dan penanganan barang mulai dari penerimaan, penyimpanan, sampai saat barang-barang yang siap untuk dijual.

\section{Prosedur Pengendalian Penerimaan Barang Dagang}

Menurut Hery (2009), pengendalian internal atas persediaan seharusnya dimulai pada saat barang diterima (yang dibeli dari pemasok). Laporan penerimaan barang yang bernomor urut tercetak, seharusnya disiapkan oleh bagian penerimaan untuk menetapkan tanggung jawab awal atas persediaan. Untuk memastikan bahwa barang yang diterima sudah sesuai dengan apa yang dipesan, setiap laporan penerimaan barang harus dicocokkan dengan formulir pesanan pembelian yang asli. Pengendalian internal atas persediaan juga seringkali melibatkan bantuan alat pengaman, seperti kaca dua arah, kamera, sensor magnetik, kartu akses gudang, pengatur suhu ruangan, petugas keamanan dan sebagainya.

\section{Prosedur Pengendalian Penyimpanan Barang Dagang}

Menurut Hery (2009), penggunaan sistem pencatatan perpetual juga memberikan pengendalian yang efektif atas persediaan. Informasi mengenai jumlah atas masingmasing jenis persediaan barang dagangan dapat segera tersedia dalam buku besar 
pembantu untuk masing-masing persediaan. Untuk menjamin keakuratan besarnya persediaan yang dilaporkan dalam laporan keuangan, perusahaan dagang seharusnya melakukan pemeriksaan fisik atas persediaanya.

\section{Prosedur Pengendalian Pengeluaran Barang Dagang}

Menurut Arianti (2003), fungsi gudang mengeluarkan barang harus sesuai dengan daftar kebutuhan barang yang telah disetujui. Setiap terjadi penerimaan dan pengeluaran barang harus dicatat dalam dokumen. Dokumen juga menjamin keseragaman dan memudahkan pengisian serta mempercepat informasi pengeluaran barang dagang. Selain itu, Aktivitas pengendalian yang diperlukan dalam pengendalian internal pengeluaran barang dagang harus di otorisasi oleh kepala bagian gudang.

Syarat-Syarat Keefektifan Pengendalian Internal Pengelolaan persediaan Barang Adapun syarat-syarat pengelolaan sediaan barang yang efektif menurut Willson dan Campbell (1997) adalah sebagai berikut.

1. Penetapan tanggung jawab dan kewenangan yang jelas.

2. Sasaran dan kebijakan yang dirumuskan dengan baik.

3. Fasilitas pergudangan dan penanganan yang memadai.

4. Klasifikasi dan identifikasi persediaan secara layak.

5. Standarisasi dan simplikasi persediaan.

6. Catatan dan laporan yang cukup.

7. Tenaga kerja yang memuaskan.

\section{METODE PENELITIAN}

\section{Lokasi Penelitian}

Penelitian tugas akhir ini dilaksanakan pada PT. Samsung Electronics Indonesia cabang Manado yang terletak di Jl. Toar No. 1, Manado Sulawesi Utara pada divisi elektronik. Divisi ini bergerak dalam distribusi barang-barang elektronik seperti TV, Kulkas, AC, Mesin Cuci, dan peralatan elektronik rumah yang dibutuhkan. Selain itu, divisi ini juga bertanggung jawab atas proses pengiriman barang dan pengendalian stok persediaan di gudang cabang manado. Alasan memilih tempat ini bertujuan untuk melihat bagaimana efektivitas pengendalian internal atas persediaan barang dagang pada PT. Samsung Electronics Indonesia cabang Manado.

\section{Metode Pengumpulan Data}

Dalam penelitian ini penulis akan menggunakan data primer dan data sekunder. Data primer yang akan digunakan berupa hasil wawancara serta observasi langsung dengan admin order desk dan pihak gudang serta pihak - pihak yang terkait dengan pengiriman barang. Sedangkan data sekunder yang digunakan dalam penelitian ini adalah literatur yang berhubungan dengan pengujian pengendalian, dokumentasi perusahaan, data jenis stok persediaan yang available digudang, alur proses pengiriman dan penerimaan barang dan data-data lain yang berhubungan dengan penelitian ini. Pada penelitian ada beberapa teknik untuk pengumpulan data yang berkaitan dengan penelitian ini. Teknik pengumpulan data terdiri dari (Sugiyono, 2006).

1. Interview (wawancara)

2. Observasi

Adapun prosedur yang akan digunakan dalam penelitian ini adalah prosedur wawancara dan observasi dimana peneliti melakukan pengamatan langsung dilapangan terhadap pokok permasalahan yang dihadapi.

\section{Metode Analisis}

Pada penelitian ini, metode analisis yang digunakan adalah analisis deskriptif dengan memperhatikan prosedur pemahaman pengendalian internal melalui pengujian 
pengendalian, kemudian mendokumentasi informasi pengendalian internal perusahaan tersebut dengan menggunakan bagan alur proses pengiriman barang dan penerimaan barang serta unsur-unsur pengendalian internal yang diterapkan kemudian di analisa dan dibuat kesimpulan.

\section{HASIL PENELITIAN DAN PEMBAHASAN}

Sejarah PT. Samsung Electronics Indonesia Cabang Manado

Demi melaksanakan pelayanan pada konsumen, PT. Samsung Electronics Indonesia menghadirkan kantor cabang dan Service Center (pusat servis) di Manado. Pembukaan cabang baru merupakan satu di antara bukti nyata PT. Samsung Electronics Indonesia dalam memperkuat komitmennya di seluruh penjuru Indonesia. Konsumen Samsung di Sulawesi Utara, khususnya Manado dapat lebih yakin memilih produk Samsung karena kini perwakilan Samsung telah hadir bersama melayani konsumen secara menyeluruh. Sejak kehadirannya di Indonesia 1991, PT. Samsung Electronics Indonesia terus berkembang dan menjadi salah satu di antara perusahaan elektronik terdepan di Indonesia. Dengan visi dan misi untuk menjadi perusahaan yang dicintai konsumen di Indonesia, Samsung terus memperkuat jaringan distribusinya dengan membuka cabang baru dan Service Center di beberapa daerah potensial di Indonesia. Sampai saat ini, Samsung memiliki 18 kantor cabang di 16 kota di Indonesia, yang di dukung dengan 84 lokasi layanan purna jual di 54 kota di Indonesia. Kota Manado merupakan salah satu Kota yang memberikan kontribusi positif terhadap perekonomian nasional seiring dengan pertumbuhan ekonomi daerah yang positif dan stabil juga dikarenakan masyarakat Kota Manado memiliki sifat konsumtif terhadap tren teknologi, sehingga menjadikan Kota Manado sebagai Kota yang memiliki potensi besar untuk penjualan elektronik dari Samsung. Kantor cabang dan Service Center PT. Samsung Electronics Indonesia berada di JL. Toar Nomor 1 Manado 95111.

\section{Hasil Penelitian}

\section{Prosedur Penerimaan Barang dari Kantor Pusat ke Gudang Manado}

Adapun prosedur penerimaan barang yang terjadi di Samsung Manado dengan Kantor Pusat Samsung yaitu sebagai berikut.

1. Pimpinan Cabang. Prosedur penerimaan barang di gudang manado melibatkan 4 pihak. Pihak pertama yaitu pimpinan cabang. Pimpinan cabang akan memesan barang yang dibutuhkan ke pusat melalui sistem SAP.

2. Kantor Pusat. Kantor pusat yang merupakan pihak kedua dalam penerimaan barang akan meng-approve permintaan barang dan mengirim barang sesuai permintaan dan kuota yang ditentukan kantor pusat.

3. Gudang Manado. Pihak gudang Manado akan menerima stok persediaan barang atas penerimaan dan kuota yang ditentukan oleh kantor pusat. Selanjutnya, pihak gudang akan melaporkan data persediaan digudang melalui email ke pihak admin order desk mengenai GR STO inbound warehouse yang merupakan list barang persediaan yang baru masuk digudang dalam bentuk Microsoft excel dengan jenis barang pada Tabel 4.1 Jenis Persediaan AV dan Tabel 4.2 Jenis Persediaan HA.

4. Admin Order Desk. Admin order desk sebagai pihak ke empat menerima email berupa GR STO inbound warehouse Manado dan persediaan barang dagangan otomatis masuk di stok available warehouse Manado

5. di sistem SAP. Gambar 4.2 memperlihatkan prosedur penerimaan barang dagangan kantor pusat ke gudang Manado. 
PRUSEDUR PENERIMIAAN GARANG DARI RANI OR PUEAI ME GUDANG IMANAUO

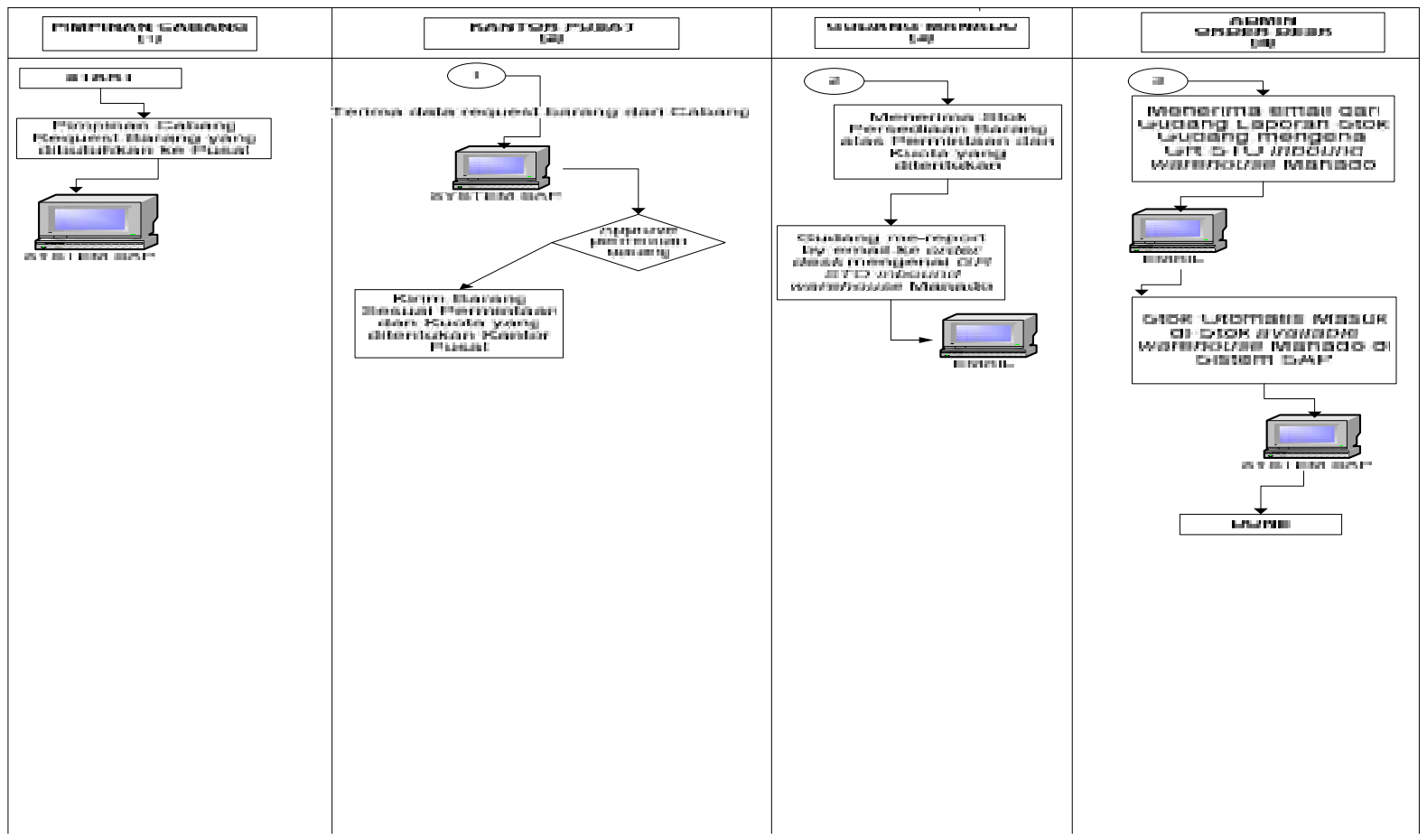

Sumber: PT. Samsung Electronics Indonesia Cabang Manado, diolah 


\section{Prosedur Penyimpanan Persediaan Barang di Gudang Samsung Manado}

Prosedur penyimpanan persediaan barang digudang Samsung Manado yaitu sebagai berikut.

1. Pihak Gudang. Persediaan barang dagangan Samsung Manado disimpan dalam gudang Samsung Manado. Dalam pengaturan penyimpanan, barang dagang Samsung Manado disimpan berdasarkan jenis persediaan barang dagang secara teratur dengan tipenya masing-masing. Hal ini bertujuan untuk mempermudah dalam mengontrol barang dagangan. Prosedur penyimpanan barang dagang Samsung Manado dilakukan dengan cara mencatat barang masuk serta barang keluar secara manual menggunakan kartu stok dan juga secara terkomputerisasi menggunakan SAP.

2. Branch Controller (BC). Setiap 6 bulan sekali pihak gudang dengan pihak BC akan melakukan stok opname untuk semua jenis barang yang ada digudang. Hal ini dilakukan untuk mencocokkan data dalam sistem dengan fisik barang yang ada di gudang dalam menunjang pengendalian internal atas barang persediaan dagangan yang ada.

\section{Proses Pemesanan Barang sampai Pengeluaran Barang PT. Samsung Electronics Indonesia Cabang Manado}

Prosedur pemesanan barang sampai pengeluaran barang Samsung Manado yaitu sebagai berikut.

1. Sales. Pihak sales melakukan pemesanan barang ke pihak kedua yaitu dealer Samsung dalam bentuk Purchase Order (PO) dan harus di isi sesuai dengan permintaan.

2. Dealer Samsung. Pihak dealer akan menerima purchase order (PO) untuk pemesanan barang. PO diisi sesuai dengan barang yang akan di pesan. Setelah itu PO yang sudah diisi dibawah kembali ke kantor untuk di input ke sistem oleh admin order desk.

3. Admin Order Desk. Admin order desk menerima PO yang nantinya akan di input ke sistem SAP. Sistem yang digunakan dalam penginputan pesananan barang Samsung Manado yaitu menggunakan System Application Product (SAP). Sebelum di input ke sistem SAP admin order desk memberikan PO untuk di verifikasi dan ditanda tangani oleh branch controller (BC) sebagai pihak ke empat.

4. Branch Controller (BC). Pihak BC menerima PO untuk di verifikasi dan ditanda tangani. Setelah BC melakukan verifikasi dan sudah di approve, PO tersebut dikembalikan lagi ke admin order desk untuk di input ke dalam SAP.

5. Pihak Gudang. Pihak gudang sebagai pihak ke lima akan menerima data pemesanan barang dari admin order desk dengan menggunakan sistem cello yang sudah terhubung dengan sistem SAP dan nantinya akan dikirim ke pihak dealer Samsung sesuai dengan pesanan barang. Pihak gudang mengecek di sistem cello kemudian menerbitkan delivery order (DO) untuk melakukan pengiriman barang yang sudah dijadwalkan oleh admin order desk. Kemudian, barang yang dipesan dikirim bersama dengan DO yang sudah diterbitkan. DO ditandatangani oleh pihak dealer sebagai bukti bahwa barang tersebut sudah diterima ditoko. Selanjutnya DO tersebut diserahkan kembali ke pihak Samsung Manado untuk keperluan finance. DO yang diterbitkan di buat 5 rangkap. Rangkap 1 diberikan kepada pihak finance sebagai pihak ke enam. Rangkap 2 diberikan kepihak dealer sebagai tagihan atas pemesanan 
barang. Selanjutnya untuk Rangkap 3 sampai 5 diberikan kepada pihak gudang sebagai data arsip gudang.

6. Pihak Finance. Pihak finance akan menerima delivery order (DO) untuk melakukan penagihan ke pihak dealer. 
PROSES ORDER BARANG

PT. SAMSUNG ELECTRONICS INDONESIA CABANG MANADO

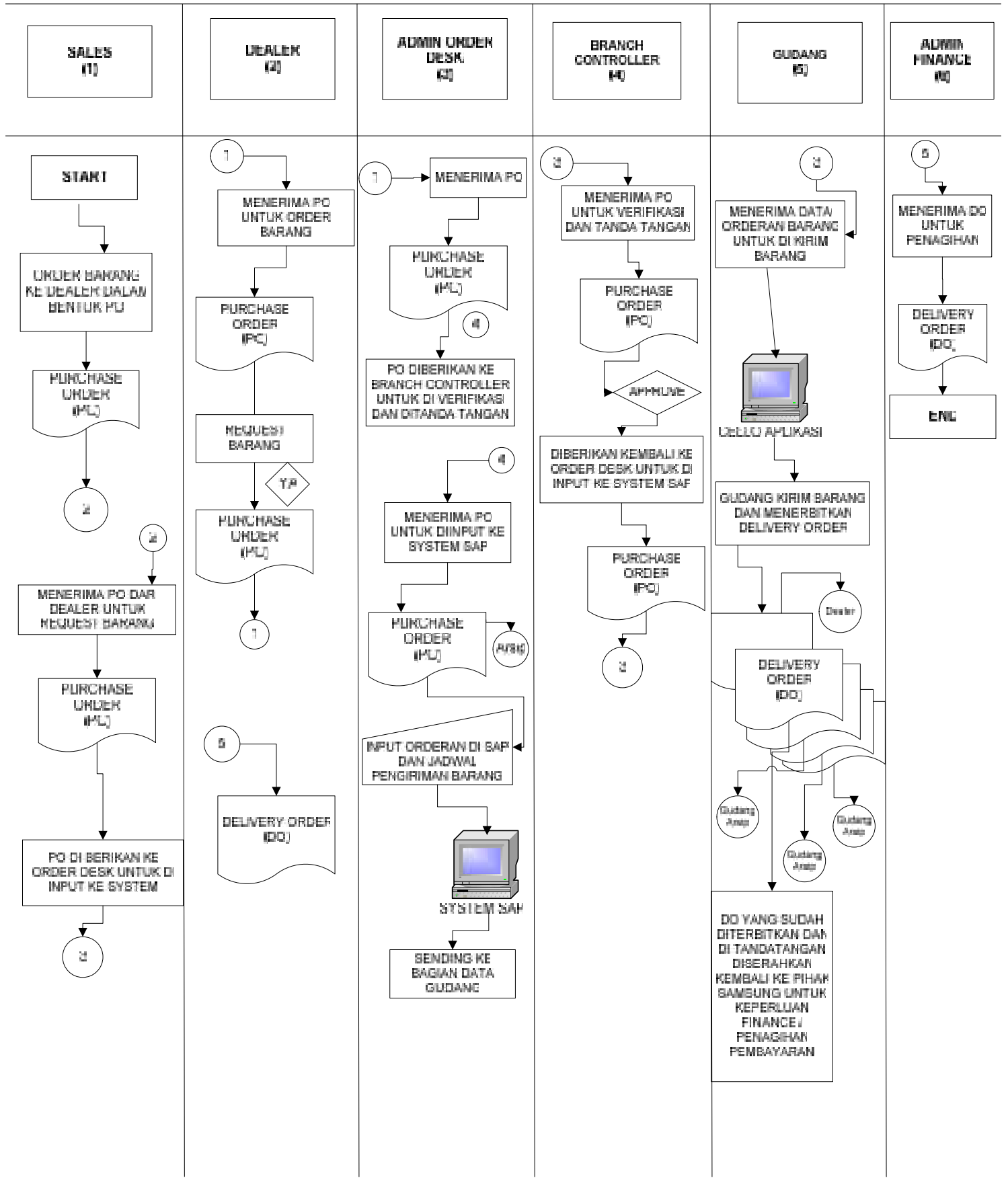

Sumber: PT. Samsung Electronics Indonesia Cabang Manado, diolah 
Pembahasan pengendalian internal menurut unsur-unsur COSO di PT. Samsung Electronics Indonesia Cabang Manado

\begin{tabular}{|c|c|c|c|c|}
\hline & $\begin{array}{c}5 \text { Unsur } \\
\text { Pengendalian }\end{array}$ & Menurut Teori & $\begin{array}{c}\text { Penerapan di PT. Samsung } \\
\text { Electronics indonesia Cabang } \\
\text { Manado }\end{array}$ & $\begin{array}{c}\text { terapkan / } \\
\text { tidak terapkan }\end{array}$ \\
\hline 1 & $\begin{array}{l}\text { Lingkungan } \\
\text { Pengendalian }\end{array}$ & $\begin{array}{l}\text { Lingkungan pengendalian } \\
\text { merupakan dasar untuk semua } \\
\text { komponen pengendalian } \\
\text { internal menyediakan disiplin } \\
\text { dan struktur. }\end{array}$ & $\begin{array}{l}\text { proses pemesanan barang yang harus } \\
\text { melalui beberapa pihak secara } \\
\text { terstruktur dan perusahaan sudah } \\
\text { melaksanakan dan menjalankan } \\
\text { dengan baik sesuai dengan aturan dan } \\
\text { kebijakan yang ada. }\end{array}$ & terapkan \\
\hline 2 & Penilaian Resiko & $\begin{array}{l}\text { identifikasi perusahaan dan } \\
\text { analisis terhadap risiko yang } \\
\text { relevan untuk mencapai } \\
\text { tujuannya, membentuk suatu } \\
\text { dasar untuk menentukan } \\
\text { bagaimana risiko harus } \\
\text { dikelola. }\end{array}$ & $\begin{array}{l}\text { mencegah terlambat melunasi } \\
\text { pembayaran (overdue) perusahaan } \\
\text { memblokir semua sistem inputan bagi } \\
\text { dealer yang sedang dalam masa } \\
\text { overdue, mencegah resiko persediaan } \\
\text { digudang habis dengan melakukan } \\
\text { pengadaan kuota setiap bulannya, } \\
\text { risiko persediaan menumpuk. }\end{array}$ & terapkan \\
\hline 3 & $\begin{array}{l}\text { Aktivitas } \\
\text { Pengendalian }\end{array}$ & $\begin{array}{l}\text { Kebijakan dan prosedur yang } \\
\text { membantu menjamin bahwa } \\
\text { arahan manajemen } \\
\text { dilaksanakan. Aktivitas } \\
\text { tersebut membantu memastikan } \\
\text { bahwa tindakan yang } \\
\text { diperlukan untuk } \\
\text { menanggulangi resiko dalam } \\
\text { pencapaian tujuan perusahaan. } \\
\text { (Pemisahaan Tugas, } \\
\text { Pengendalian fisik, telaah } \\
\text { Kinerja) }\end{array}$ & $\begin{array}{l}\text { Adanya pemisahan tugas dalam } \\
\text { proses pemesanan barang, Setiap } \\
\text { divisi menjalankan sesuai dengan } \\
\text { tugas mereka masing-masing. }\end{array}$ & terapkan \\
\hline & $\begin{array}{l}\text { Informasi dan } \\
\text { Komunikasi }\end{array}$ & $\begin{array}{l}\text { Pengidentifikasian, } \\
\text { penangkapan, dan pertukaran } \\
\text { informasi dalam suatu bentuk } \\
\text { dan waktu yang } \\
\text { memungkinkan orang } \\
\text { melaksanakan tanggung jawab } \\
\text { mereka. }\end{array}$ & $\begin{array}{l}\text { untuk informasi persediaan digudang } \\
\text { admin sales setiap harinya mendapat } \\
\text { informasi persediaan barang } \\
\text { dagangan digudang yang nantinya } \\
\text { dishare ke pihak-pihak yang } \\
\text { membutuhkan informasi ini. Dari } \\
\text { hasil pemantauan juga komunikasi } \\
\text { dilapangan untuk setiap hal yang } \\
\text { terjadi selalu dikomunikasikan setiap } \\
\text { saat melalui sistem dan melalui } \\
\text { telepon selular yang menggunakan } \\
\text { whatsapp. }\end{array}$ & Terapkan \\
\hline
\end{tabular}


5 Pemantauan dan Pemantauan mencakup Monitoring penentuan desain dan operasi pengendalian tepat waktu dan pengambilan tindakkan koreksi. Proses ini dilaksanakan melalui kegiatan yang berlangsung secara terus menerus, evaluasi secara terpisah, atau dengan berbagai kombinasi dari keduanya.
Samsung Cabang Manado melakukan Terapkan pemantauan setiap saat . Pada saat DO sudah diterbitkan tetapi belum dijadwalkan, Barang Masuk dan keluar di pantau atau diperiksa melalui sistem yang digunakan untuk memberikan informasi yang tepat.

\section{KESIMPULAN}

Setelah menganalisis dan mengevaluasi pengendalian internal atas persediaan barang dagangan pada PT. Samsung Electronics Indonesia cabang Manado, dapat disimpulkan beberapa hal yaitu sebagai berikut.

1. Lingkungan Pengendalian. Lingkungan pengendalian pada Perusahaan Samsung Manado sudah berjalan terstruktur dan disiplin. Namun dalam hal kedisiplinan masih juga ada beberapa karyawan yang tidak patuh dan sering terlambat. Tindakan yang di atasi yaitu dengan gaji karyawan yang akan dipotong serta akan diberikan Surat Peringatan apabila karyawan masih terlambat.

2. Penilaian Resiko. Resiko yang terjadi dalam perusahaan yaitu sebagai berikut.

a. Pada saat overdue. Hal ini terjadi apabila dealer terlambat melunasi pembayaran. Admin order desk tidak bisa melakukan penjadwalan untuk kirim barang atau penerbitan delivery order (DO). Tentunya hal ini dilakukan agar dealer harus tetap membayar tagihan tepat waktu dan harus melunasi terlebih dahulu agar supaya bisa melakukan pemesanan kembali.

b. Persediaan barang digudang habis. Hal ini diantisipasi untuk setiap bulannya kantor pusat melakukan pengadaan kuota untuk setiap cabang Samsung.

c. Persediaan barang dagang menumpuk. Hal ini akan dipantau oleh pusat melalui sistem SAP dan kantor pusat akan menagih kenapa barang yang dikirim belum bisa dibuatkan delivery order.

3. Aktivitas Pengendalian. Pada Perusahaan Samsung Manado untuk proses bisnis nya dikendalikan oleh BM dan BC. Samsung Manado juga sudah menerapkan pemisahan tugas, pengendalian fisik, serta Telaah kinerja sehingga aktivitas tersebut membantu memastikan bahwa tindakan yang diperlukan untuk menanggulangi risiko dalam pencapaian tujuan Samsung Manado.

4. Komunikasi dan Informasi. Dari hasil pemantauan lapangan setiap hal yang terjadi selalu dikomunikasikan setiap saat yaitu melalui sistem dan melalui telepon selular yang menggunakan Whatsapp dan telepon selular.

5. Aktivitas Pemantauan. Samsung cabang Manado juga melakukan pemantauan atau monitoring setiap saat melalui sistem yang digunakan.

Berdasarkan kesimpulan di atas, maka penulis berusaha untuk memberikan saran kepada Samsung cabang Manado yang bisa bermanfaat dalam mengatasi kelemahan yang terdapat dalam sistem pengendalian internal atas persediaan barang dagangan. Adapun saran - saran yang dapat diberikan oleh penulis yaitu sebagai berikut.

1. Untuk lingkungan pengendalian mengenai kedisiplinan lebih ditingkatkan lagi terlebih bagi karyawan yang masih terlambat.

2. Untuk resiko yang terjadi yaitu overdue, persediaan barang digudang habis, dan persediaan menumpuk, agar lebih diperhatikan perusahaan dan menjalankan sesuai prosedur perusahaan serta lebih ditingkatkan lagi penanganan dalam 
persediaan barang dagang sehingga tidak menumpuk dan lebih yang ditunjang juga dengan komunikasi yang jelas. Terlenbih bagi pihak gudang dan pihak sales perlu untuk meningkatkan lagi informasi persediaan yang kelebihan. Setiap bulannya pihak gudang mengingatkan sales dalam hal penyimpanan barang yang menumpuk dan segera melaporkan persediaan lebih ke pusat agar tidak terjadi penumpukkan barang dan tidak dikuotakan di bulan berikutnya.

3. Untuk aktivitas pengendalian yang sudah baik dijaga terus agar bisa mengurangi hal-hal dalam kecurangan dan penyelewangan yang bisa terjadi.

4. Untuk komunikasi dan Informasi terus dijaga dalam menunjang operasional perusahaan.

5. Untuk pemantauan dan monitoring setiap saat selalu dijaga agar bisa tetap berjalan sesuai prosedur perusahaan yang sudah ada.

\section{DAFTAR PUSTAKA}

Agnia, H. (2009), "Evaluasi Pengendalian Internal atas Kegiatan Pengelolaan Persediaan Pada PT. X," Skripsi Fakultas Ekonomi Universitas Indonusa Esa Unggul Jakarta (tidak dipublikasikan)

Aini, (2011), Manajemen Persediaan, Edisi 1, Jakarta.

Arens, Elder, and Beasly, (2008), Auditing dan Jasa Assurance: Pendekatan Terintegrasi, Edisi 2, Volume 1 Erlangga, Jakarta.

Arianti, D. F. (2003), "Evaluasi Sistem Akuntansi Pengeluaran Barang Pada PT. Amalia Surya Cemelang," Skripsi Fakultas Ekonomi Surakarta (tidak dipublikasikan)

Cheruiyot, S. K. (2014), "Effectiveness of Internal Control Systems In Safeguarding Inventory," Master of Business Administration Kabarak University. (tidak dipublikasikan)

CPA Australia, (2008), "Internal Controls for Small Business," CPA Australia Ltd. (tidak dipublikasikan)

Diamonalisa, Oktaroza, M. L., and Jatmika, E. T. (2014), "Analisis dan Perancangan Sistem Informasi Persediaan Barang di Toko Sofia," Skripsi Fakultas Ekonomi Universitas Islam Bandung (tidak dipublikasikan)

Dinapoli, T. (2010), Management's Responsibilty For Internal Controls Edisi 1, Division of Local Government and School Accountability, New York.

Fariyanti, R. (2013), "Analisa Kefektifan Pengendalian Internal Sistem Persediaan Pada PT. CASSANATAMA NATURINDO," Skripsi Fakultas Ekonomi dan Bisnis Universitas Dian Nuswantoro Semarang (tidak dipublikasikan)

Handayani, S. (2009), "Evaluasi Pengendalian Internal Sediaan Barang Pada Toko Kesongo," Skripsi Fakultas Ekonomi dan Bisnis Universitas Dian Nuswantoro Semarang (tidak dipublikasikan)

Hery. (2009), Akuntansi Intermediate Ilustrasi Problem Dan Solusi, Edisi 1, Grasindo, Jakarta..

Makisurat, A., Morasa, J., and Elim, I. (2014), "Penerapan Sistem Pengendalian Intern Untuk Persediaan Barang Dagangan Pada CV. Multi Media Persada Manado," Skripsi Skripsi Fakultas Ekonomi dan Bisnis Universitas Sam Ratulangi Manado (tidak dipublikasikan)

Mihaela, D., and lulian, S. (2012), "Internal Control and the Impact on Corporate Governance in Romanian Listed Companies," Journal of Eastern Europe Research in Business \& Economics. (tidak dipublikasikan) 
Mina, S., \& Dahria, M. (2010), “Analisis Sistem Persediaan Dalam Akuntansi,”Skripsi Fakultas Ekonomi dan Bisnis Universitas Sam Ratulangi Manado (tidak dipublikasikan)

Mulyadi. (2008), Sistem Akuntansi, Edisi 3, Bagian Penerbitan Sekolah Tinggi Ilmu Ekonomi YKPN, Yogyakarta .Mulyani, S. (2013), "Analisis Pengendalian Intern Atas Persediaan Barang Dagangan Pada PT. Grokindo," Skripsi STIE Pertiwi (tidak dipublikasikan)

Nurmailiza, (2009), "Analisis Pengendalian Internal Atas Persediaan Barang Dagang Pada PT. Sabda Cipta Jaya," Skripsi Fakultas Ekonomi Medan Universitas Sumatra Utara (tidak dipublikasikan)

Victoria, O. I., and I., Ukpere, W. (2014), “ The Impact of Effective Inventory Control Management on Organisational Performance: A Study of 7up Bottling Company Nile Mile Enugu, Nigeria," Mediterranean Journal of Social Sciences. (tidak dipublikasikan)

Radiani, D. (2004), "Peranan Pengendalian Internal Persediaan Barang Dagangan Dalam Menunjang Efektivitas Pengelolahan Persediaan Barang Dagangan," Skripsi Fakultas Ekonomi Widyatama (tidak dipublikasikan)

Rahmawati, L. O. (2010), "Evaluasi Sistem Pengendalian Intern Atas Persediaan Farmasi yang Ditetapkan Pada PT. KIMIA FARMA Trading dan Distribution Surakarta," Skripsi Fakultas Ekonomi Universitas Sebelas Maret Surakarta (tidak dipublikasikan)

RAI, I. A. (2008), Audit Kinerja Pada Sektor Publik Konsep Praktik dan Studi Kasus, Edisi 1, Volume 1, Salemba Empat, Jakarta.

Seredei, S., and Runtu, T. (2015), "Evaluasi Penerapan Pengendalian Intern Atas Persediaan Barang Dagangan Pada PT. Suramando (Distributor Farmasi dan General Supplier) di Manado," Skripsi Fakultas Ekonomi Universitas Sam Ratulangi Manado (tidak dipublikasikan)

Syailendra, B. (2013), "Analisis faktor-faktor yang berpengaruh terhadap pemilihan metode penilaian persediaan," Skripsi Universitas Diponegoro (tidak dipublikasikan)

Tunggal, A. (2013), Pokok-pokok COSO - Based Auditing, Edisi 1, Harvarindo, Jakarta

Warren, R. F. (2008), Akuntansi Keuangan Daerah, Edisi 3, Salemba Empat, Jakarta.

Warren, R. F. (2006), Pengantar Akuntansi, Edisi 21, Volume 1, Salemba Empat, Jakarta 